\title{
MARGINAL BONE LOSS AND AESTHETICS AROUND ZIRCONIA AND TITANIUM DENTAL IMPLANTS-A METANALYSIS
}

\section{Pulijala Sathwika BDS}

Post-Graduate

Department of Periodontics

SVS Institute of Dental Sciences

Yedira Post

Mahabubnagar

Telangana, India

\section{Rampalli Viswa Chandra* MDS;DNB;PhD}

Professor and Head

Department of Periodontics

SVS Institute of Dental Sciences

Yedira Post

Mahabubnagar

Telangana, India

\section{*Corresponding Author}

Rampalli Viswa Chandra

Professor and Head

Department of Periodontics

SVS Institute of Dental Sciences

Mahabubnagar 509002

Telangana, India

Phone: 91-8542-271515, Fax: 91-8542-273111

Email: viswachandra@hotmail.com 
medRxiv preprint doi: https://doi.org/10.1101/2020.05.09.20096271; this version posted May 13,2020 . The copyright holder for this preprint (which was not certified by peer review) is the author/funder, who has granted medRxiv a license to display the preprint in perpetuity.

All rights reserved. No reuse allowed without permission.

\title{
MARGINAL BONE LOSS AND AESTHETICS AROUND ZIRCONIA AND TITANIUM DENTAL IMPLANTS-A METANALYSIS
}

\begin{abstract}
AIM: To evaluate and compare the marginal bone loss and aesthetic outcomes of zirconia implants with titanium implants in randomized controlled trials (RCTs).
\end{abstract}

MATERIAL AND METHODS: Electronic [PubMed] and hand searches were performed to identify randomized controlled trials that were published between January 2008 to April 2020 which investigated and compared various outcomes between zirconia and titanium dental implants. Outcomes included assessment of marginal bone loss and aesthetics using spectrophotometric measurements. Meta-analysis was performed to estimate the above parameters among various studies.

RESULTS: A total of 58 articles were screened for titles and abstracts. Subsequently 8 articles were selected for data extraction and evaluation. Zirconia implants were investigated and compared to titanium implants for marginal bone loss [MBL]. Customized zirconia and titanium abutments seated over implants were analyzed for aesthetic outcomes using spectrophotometric method using CIE-Lab measurements. Meta-analysis estimated that zirconia implants exhibited marginal bone loss reduction of $0.179 \mathrm{~mm}(95 \% \mathrm{CI}, 0.02$ to 0.33 ) and $-0.242 \mathrm{~mm}$ (95\% CI, -4.026 to 3.542$)$ in aesthetic measurements than titanium implants.

CONCLUSIONS: No heterogeneity was observed among studies analyzed for marginal bone loss and significant differences were noticed between two groups. Noticeable heterogeneity was observed among studies assessing aesthetics using spectrophotometry and CIE-Lab measurements and results revealed no many significant differences between the two groups.

Keywords: Zirconia implants, Titanium Implants, Peri-implant marginal bone loss, Implant aesthetics, Randomized controlled trials. 
medRxiv preprint doi: https://doi.org/10.1101/2020.05.09.20096271; this version posted May 13, 2020. The copyright holder for this preprint (which was not certified by peer review) is the author/funder, who has granted medRxiv a license to display the preprint in perpetuity.

All rights reserved. No reuse allowed without permission.

\section{INTRODUCTION}

In the last few decades, the rehabilitation of partially and completely edentulous patients with implant-supported prostheses has become a common practice with reliable longterm results and survival rates higher than $90 \% .^{1-3}$ Currently, titanium implants are widely used in implant dentistry due to their osseointegration, biocompatibility, biomechanical properties, clinical reliability, excellent material stability, resistance towards distortion ${ }^{4,5}$ and high success rates. $^{6-8}$ Due to their longevity of implant-borne reconstructions in all regions of the jaw, titanium abutments are considered as 'gold-standard' till now.

However, there are certain drawbacks associated with titanium implants of which, its gray color, ${ }^{5,9,10}$ that can lead to aesthetic impairments by becoming clinically visible in patients with thin mucosal biotype or due to gingival recession, is a big concern. Recent studies have demonstrated the potential of titanium particles to cause inflammatory reactions in peri-implant tissue as a part of the biological response as well. ${ }^{11-14}$ These sensitivities and allergies associated with the failure of titanium implants ${ }^{15-17}$ and patients' concern regarding the potential health hazards of titanium and its corrosive products, ${ }^{18,19}$ have led to the development of alternative materials in implant dentistry.

Ceramic implants made of zirconium dioxide, an inert, non-resorbable, and biocompatible metal oxide with promising chemical and physical properties ${ }^{17,21}$ might serve as viable alternative in these situations due to their superior mechanical and biological properties like low thermal conductivity, low affinity to plaque and high biocompatibility. ${ }^{17,20,22}$ Moreover, Zirconia implants have a white color that mimics dental hard tissues better and can feature aesthetic benefits in the presence of a thin biotype or gingival recessions. ${ }^{20,22}$ A significant reduction in in-vitro bacterial biofilm formation and reduced numbers of inflammatory cells in 
medRxiv preprint doi: https://doi.org/10.1101/2020.05.09.20096271; this version posted May 13, 2020. The copyright holder for this preprint (which was not certified by peer review) is the author/funder, who has granted medRxiv a license to display the preprint in perpetuity.

All rights reserved. No reuse allowed without permission.

the peri-implant soft tissues of healing caps and abutments have been reported for zirconia compared with titanium. ${ }^{22,23}$ However, brittleness of ceramics, ${ }^{5,24}$ that leads to less resistance toward tensile forces and micro-structural defects, is considered as a drawback of ceramics. It is a topic of debate whether zirconia implants may cause immunological reactions similar to titanium or not. $^{25-27}$

A natural appearance of the mucogingival architecture around implant-supported restorations is one of the major treatment goals especially in aesthetically demanding situations. The display of the peri-implant mucosa may be influenced by several factors such as the color or the thickness of the mucosa. Porcelain-fused-to-metal crowns cemented to metal abutments are considered as standard for fixed reconstructions with long term and high survival rates. In such situations, visible discoloration of the peri-implant tissue may lead to aesthetic problems and the patient dissatisfaction. ${ }^{5,28,29}$ To overcome these, literature suggests the use of ceramic abutments that might offer advantages in terms of color compared to the gold standard, metal abutment. Zirconia implants and abutments in anterior and premolar regions resulted in excellent clinical success rate with minimal marginal bone loss. However, a slight discoloration of the peri-implant tissue could be detected in cases with a thin mucosa biotype even with white zirconia abutments.

To address the shortcomings and to measure the aesthetic parameters, several metrics have been recently proposed by investigators. An ordinal index was proposed by Jemt ${ }^{31}$ to systematically assess soft tissue contours adjacent to single-implant restorations. Subsequently, a more comprehensive "implant crown aesthetic index" was proposed by Meijer et al. " that included nine parameters, including both the implant crown form and peri-implant mucosal architecture, based on the adjacent and contralateral natural teeth as a reference. Concurrently, Furhauser et al. ${ }^{33}$ proposed the pink aesthetic score (PES), in which, equal weight was given to 
medRxiv preprint doi: https://doi.org/10.1101/2020.05.09.20096271; this version posted May 13,2020 . The copyright holder for this preprint (which was not certified by peer review) is the author/funder, who has granted medRxiv a license to display the preprint in perpetuity.

All rights reserved. No reuse allowed without permission.

each of the seven PES parameters, resulting in a minimum score of 0 and a maximum score of 14. Belser et al. ${ }^{34}$ more recently proposed a modified PES [PES/white aesthetic score (WES)] which combined mucosal elements (root convexity, soft tissue, color and texture) resulting in five soft tissue aesthetic criteria, and then added five additional components (form, outline/volume, color, surface texture and translucency/characterization) related to the clinical crown of the implant restoration, for a maximum score of 20 points.

Clinical studies gained many benefits from assessing and reporting the Commission Internationale de I'Eclairage $\mathrm{L}^{*}, \mathrm{a}^{*}$ and $\mathrm{b}^{*}(\mathrm{CIE}-\mathrm{Lab})$ coordinates which permits quantitative evaluation of color. These coordinates are typically obtained from spectral reference measurements using a spectrophotometer through which numerical values are obtained in three-dimensional color space. $\mathrm{L}^{*}$ coordinate ( 0 to 100$)$ represents lightness, $\mathrm{a}^{*}$ coordinate (-90 to 70) represents greenness on the positive axis and redness on the negative axis. The $b^{*}$ coordinate (-80 to 100$)$ represents yellowness (positive $\mathrm{b}^{*}$ ) and blueness (negative $\mathrm{b}^{*}$ ). The color difference $(\Delta E)$ expressed in $L^{*}, a^{*}, b^{*}$ is then calculated using the formula: $\Delta E=\left[(\Delta L)^{2}\right.$ $\left.+(\Delta \mathrm{a})^{2}+(\Delta \mathrm{b})^{2}\right]^{1 / 2} \cdot \Delta \mathrm{E}$ units of 2 to 3 are considered perceptible, and a difference of less than 2 units is considered imperceptible. ${ }^{36}$

In this context, the aim of the present meta-analysis was to evaluate and compare the marginal bone loss and aesthetic outcomes of zirconia implants with titanium implants in randomized controlled trials. 
medRxiv preprint doi: https://doi.org/10.1101/2020.05.09.20096271; this version posted May 13,2020 . The copyright holder for this preprint (which was not certified by peer review) is the author/funder, who has granted medRxiv a license to display the preprint in perpetuity.

\section{MATERIALS AND METHODS}

\section{Literature search}

A meta-analysis was conducted on the evaluation and comparison of marginal bone levels and aesthetic parameters in zirconia and titanium implants with a search for articles in the PUBMED search site. In this, a single reviewer selected English language articles published from January 2008 to April 2020, using the keywords (("zirconium oxide"[Supplementary Concept] OR "zirconium oxide"[All Fields] OR "zirconia"[All Fields]) AND implants[All Fields] AND ("esthetics"[MeSH Terms] OR "esthetics"[All Fields] OR "aesthetics"[All Fields])) AND (Randomized Controlled Trial[ptyp] OR Clinical Trial[ptyp]) and (("zirconium oxide"[Supplementary Concept] OR "zirconium oxide"[All Fields] OR "zirconia"[All Fields]) AND implants[All Fields] AND marginal[All Fields] AND ("bone diseases, metabolic"[MeSH Terms] OR ("bone"[All Fields] AND "diseases"[All Fields] AND "metabolic"[All Fields]) OR "metabolic bone diseases"[All Fields] OR ("bone"[All Fields] AND "loss"[All Fields]) OR "bone loss"[All Fields])) AND (Randomized Controlled Trial[ptyp] OR Clinical Trial[ptyp]).

\section{Inclusion and exclusion criteria:}

The studies were included based on the following criteria: English language, Human Randomized Clinical Trials (RCT) of zirconia implants and titanium implants collected from January 2008 to April 2020, studies at all levels of evidence, except expert opinions. Some studies were excluded based on the following criteria; clinical studies investigating individually designed zirconiaimplants or multiple publications on the same patient population, studies based on a questionnaire or charts or interview and studies evaluating only parameters other than aesthetics and marginal bone levels were excluded (Figure 1).

\section{Data extraction and analysis}

The titles identified by the search were screened. The abstracts of all studies of 
medRxiv preprint doi: https://doi.org/10.1101/2020.05.09.20096271; this version posted May 13,2020 . The copyright holder for this preprint

(which was not certified by peer review) is the author/funder, who has granted medRxiv a license to display the preprint in perpetuity.

All rights reserved. No reuse allowed without permission.

possible relevance were obtained and screened. When studies met the inclusion criteria or when insufficient data from abstracts were available to evaluate inclusion criteria, the full-text article was obtained. The selected papers were screened independently by the reviewers to confirm whether they met the inclusion criteria or not and disagreement among authors if any, regarding data extraction was resolved by discussion.

\section{Outcome Measures}

After data extraction, the outcomes of this study include evaluation of Marginal bone loss (MBL) assessed using radiographic methods and evaluation of aesthetics by Spectrophotometric method using CIE-Lab measurements.

\section{Statistical Analysis}

Study outcomes were reported through evidence tables and a quantitative synthesis through a meta-analysis. For data analysis, OpenMee ${ }^{\circledR}$ software was used. Means and SD were chosen for expressing the results of continuous outcomes. Heterogeneity was evaluated through Cochrane's test $\left(I^{\wedge} 2\right.$-test $)$ on the level of $\alpha=0.10$. If the heterogeneity was considerable $\left(\mathrm{I}^{\wedge} 2>50 \%\right)$, the random-effects model or subgroup analysis was employed; if the heterogeneity was non-significant, the fixed-effects model was adopted. 
medRxiv preprint doi: https://doi.org/10.1101/2020.05.09.20096271; this version posted May 13,2020 . The copyright holder for this preprint (which was not certified by peer review) is the author/funder, who has granted medRxiv a license to display the preprint in perpetuity.

All rights reserved. No reuse allowed without permission.

\section{RESULTS}

An initial screening resulted in a total of 58 articles. 10 of these articles were excluded as they duplicated during search and 40 articles were excluded as they did not meet the inclusion criteria. A total of eight articles ${ }^{5,17,19,27-29,36,37}$ were identified (Figure 1), which compared zirconia implants to titanium implants and were considered for meta-analysis. Five $\operatorname{articles}{ }^{5,17,19,27,37}$ were analyzed for marginal bone levels and four articles ${ }^{5,28,29,36}$ for aesthetics. The characteristics of these randomized controlled trials (RCTs) were summarized in Table 1.

The study by Payer et al. ${ }^{17}$ was based only on two-piece implants while Osman et al. ${ }^{19}$ rehabilitated completely edentulous patients. Most of the studies were based on the placement of single implants. There were no restrictions regarding whether implants were placed in the maxilla or mandible in any of the studies. The primary clinical outcomes of the meta-analysis are evaluation of marginal bone loss and aesthetic outcomes.

\section{Marginal Bone loss:}

Five articles ${ }^{5,17,19,27,37}$ were considered for meta-analysis to evaluate and compare marginal bone levels. Radiographs of implants made at different time points were evaluated and investigators reported outcome of marginal bone loss in all the studies. The results of the $\chi^{2}$ test that was used to assess heterogeneity revealed that there was no observed heterogeneity across the studies in reporting the outcomes of marginal bone loss ( $\mathrm{p}$ of heterogeneity $=0.536$ ). Pooled estimates showed that zirconia implants had $0.179 \mathrm{~mm}$ (95 percent confidence interval [CI], 0.02 to 0.33 ) more marginal bone loss reductions than did titanium implants, there was a high statistical difference between the two treatment groups $(\mathrm{p}=0.028)$ (Figure 2).

\section{Aesthetic Outcome:}

Four articles ${ }^{5,28,29,36}$ were considered for meta-analysis to evaluate and compare 
medRxiv preprint doi: https://doi.org/10.1101/2020.05.09.20096271; this version posted May 13,2020 . The copyright holder for this preprint (which was not certified by peer review) is the author/funder, who has granted medRxiv a license to display the preprint in perpetuity.

All rights reserved. No reuse allowed without permission.

aesthetics. All these studies used spectrophotometry method and color measurement data was evaluated using CIE-Lab parameters (L=lightness; a=chroma along the red-green axis and $\mathrm{b}=$ chroma along the yellow-blue axis). The following equation was applied to assign the overall color difference $\Delta \mathrm{E}=\left[(\Delta \mathrm{L})^{2}+(\Delta \mathrm{a})^{2}+(\Delta \mathrm{b})^{2}\right]^{1 / 2}$ and finally $\Delta \mathrm{E}$ values were compared. The results of the $\chi^{2}$ test that was used to assess heterogeneity revealed that there was an observed heterogeneity across the studies in reporting the aesthetic outcomes using CIE-Lab measures ( $\mathrm{p}$ of heterogeneity <0.001). Pooled estimates showed that zirconia implants had $0.242 \mathrm{~mm}$ (95 percent confidence interval [CI], -4.026 to 3.542) aesthetic outcome than did titanium implants, there was no statistical difference between the two treatment groups $(\mathrm{p}=0.90)$ (Figure 3). 
medRxiv preprint doi: https://doi.org/10.1101/2020.05.09.20096271; this version posted May 13,2020 . The copyright holder for this preprint (which was not certified by peer review) is the author/funder, who has granted medRxiv a license to display the preprint in perpetuity.

All rights reserved. No reuse allowed without permission.

\section{DISCUSSION}

In the last few years, the field of dental implantology has witnessed a lot of advances in multiple areas which include new materials, micro-and macro-designs and new surface technologies. There has been a tremendous increase in understanding of the factors affecting marginal bone levels, aesthetics, peri-implantitis, and implant success rate. All these advances have led to an increase in the success and survival rates of titanium implants (up to $97.2 \%$ after 5 years) which was reported in several studies in the literature.

While designing, the vast majority of dental implants consider titanium as the main material of choice due to its characteristics such as biocompatibility, low corrosion, and high resistance. However, literature has reported various complications related to this material ${ }^{15,42-}$ 47

and have led to the investigations on other materials. Alumina and crystal-sapphire aluminium oxide, the first material proposed, failed because of their low mechanical and physical properties. ${ }^{48}$ Later Yttria-stabilized zirconia ceramic (Y-TZP; Zi implants) was proven as a good alternative to Titanium because of its biocompatibility, resistance to fracture \& compression, aesthetic acceptability and low bacterial adherence.

$18,41,49-51$

Experiments conducted on various animal models have demonstrated osseointegration of threaded zirconia implants. A study conducted by Akagawa et al. ${ }^{52}$ compared the bone tissue response to loaded and unloaded zirconia implants in dog mandible. Scarano et al. ${ }^{53}$ conducted a study and investigated the bone response to 20 YTZP implants, which were inserted in the tibiae of five rabbits. According to most authors, implants show osseointegration without signs of inflammation or mobility. ${ }^{54}$

This meta-analysis was conducted to evaluate marginal bone loss and aesthetic outcomes in zirconia implants and to compare them with titanium implants. Marginal bone loss was considered as one of the primary outcomes along with the aesthetics assessed using 
medRxiv preprint doi: https://doi.org/10.1101/2020.05.09.20096271; this version posted May 13, 2020. The copyright holder for this preprint (which was not certified by peer review) is the author/funder, who has granted medRxiv a license to display the preprint in perpetuity.

All rights reserved. No reuse allowed without permission.

spectrophotometry method and CIE-Lab measures. It has been shown in numerous studies that bone resorption around the implant neck starts only when the implant is uncovered and exposed to the oral cavity, invariably leading to bacterial contamination of the gap between the implant and the superstructure. ${ }^{55}$ There will be a progression of bone remodeling until the biologic width has been created and stabilized. This width not only does progress apically, along the vertical axis, but there is also a horizontal component amounting to 1-1.5 $\mathrm{mm}$ according to studies conducted by Tarnow et al. ${ }^{56}$ Therefore, the authors stated that the main factor contributing to the reduction of marginal bone loss in zirconia dental implants is its one-piece morphology in which there is no micro-gap between the implant and the abutment and hence less microbial contamination and absence of micro-movements of the prosthetic component.

Another factor that led to a reduction of marginal bone loss is reduction of bacteria on the surface of zirconia. Bacterial adhesion to implant surfaces is the first stage of periimplant mucositis and peri-implantitis; in fact, a positive correlation has been found between oral hygiene and marginal bone loss around implants. ${ }^{57}$ In a study conducted by Scarano et al. ${ }^{58}$ bacterial adhesion between zirconium oxide and titanium surfaces were compared and there was a significantly lesser bacteria on zirconium oxide surfaces, which promoted early formation of the biologic width and mucosal seal preventing early marginal bone resorption. ${ }^{54}$

In this meta-analysis, some studies evaluated outcomes of single piece zirconia implants and some studies utilized two-piece zirconia implants. Due to their fixed abutment position, single-piece implants were less forgiving in terms of planning and surgical execution when compared to two-piece implants. ${ }^{59,60}$ However, luting of the abutment-implant connection has its own technical challenges which included a complex procedure of placing a rubber dam at the fixture level to maintain an appropriate field for luting. On the other hand, the full view of the implant abutment interface will facilitate verification of adequate seating 
medRxiv preprint doi: https://doi.org/10.1101/2020.05.09.20096271; this version posted May 13, 2020. The copyright holder for this preprint (which was not certified by peer review) is the author/funder, who has granted medRxiv a license to display the preprint in perpetuity.

All rights reserved. No reuse allowed without permission.

and removal of all excess cement to reduce any undesirable and adverse effects on peri-implant tissues. ${ }^{61,62}$ Connecting a final abutment in case of single-piece implants has its advantages when compared to two-piece implants. These advantages include reduced risk of many surgical procedures and less tissue trauma.

Payer et al. ${ }^{17}$ conducted a randomized controlled trial on two-piece zirconia implants which required second-stage surgery that is invasive and time-consuming when compared to the titanium control group. A potential disadvantage of this type of second-stage surgery would be a minor deterioration in the aesthetic outcomes due to a higher degree of tissue remodeling. It seems surprising that in the search for rational arguments for zirconia as an implant material, one is confronted with considerations of potential minor aesthetics caused by the invasiveness necessary for its application. A study conducted by Glauser et al. ${ }^{65}$ demonstrated excellent performance of zirconia abutments and a $100 \%$ survival rate of the zirconia abutments at 4 years of function. The results stated that the excellent outcome of zirconia abutments is not limited to anterior regions with lower loading forces but can also be obtained in posterior sites as well.

The studies analyzed for aesthetic outcomes in this meta-analysis used customized zirconia and customized titanium abutments over single implants. The importance of abutment material for the quality of peri-implant tissue has been reported in many previous studies. Information collected from various animal studies and human histological studies indicate that zirconium dioxide abutments may have a more favorable effect on peri-implant soft tissues. Further clinical studies are required in this aspect to prove the same. ${ }^{29}$ Normal color variance on the intraoral soft tissue is based on age and ethnicity ${ }^{67}$ and variation exists even within an individual himself. The color of the soft tissue is affected significantly by the gray shinethrough effect of the implant which can in turn contribute to the patient's perception of the 
medRxiv preprint doi: https://doi.org/10.1101/2020.05.09.20096271; this version posted May 13, 2020. The copyright holder for this preprint (which was not certified by peer review) is the author/funder, who has granted medRxiv a license to display the preprint in perpetuity.

All rights reserved. No reuse allowed without permission.

aesthetics and the treatment outcome. This so-called gray shine-through effect is, as suspected to be, due to the underlying structures such as the bone contour, implant body, abutment, metal in the restoration, and/or a combination of all these factors.

It has been reported previously that the mucosal thickness has a significant influence on the aesthetic outcome of implant-supported reconstructions. ${ }^{23}$ It was observed that the threshold value of the mucosal thickness to mask color differences by the human eye is $2 \mathrm{~mm} .^{9,69}$ There are some morphological differences in the soft tissues around dental implants when compared with the gingiva around teeth. ${ }^{70}$ One major difference is that the peri-implant mucosa contains a smaller number of vessels. ${ }^{71}$ As vascularization is demonstrated to have an influence on the color, ${ }^{72}$ this might be considered as one reason for color variations between mucosa and gingiva. The thickness of the soft tissues is another factor influencing color. ${ }^{23,28,74}$ A recent in-vitro study demonstrated that a mucosal thickness of less than $2 \mathrm{~mm}$ in both titanium and zirconia induces overall mucosal color change. With an increase in mucosal thickness, there is a decrease in color change. At a mucosal thickness of $1.5 \mathrm{~mm}$, both materials demonstrated $\Delta \mathrm{E}$ values above the critical threshold of $\Delta \mathrm{E} 3.7$ for intraoral color distinction by the naked eye. ${ }^{73}$ The color change induced by zirconia was below the threshold of $\Delta \mathrm{E} 3.7$ at a mucosa thickness of $2 \mathrm{~mm}$, whereas titanium still caused a visible difference. ${ }^{9}$ More controlled clinical studies analyzing the influence of the abutment material on the color of the surrounding tissues are necessary. ${ }^{28}$

Titanium abutment is still considered as a material of choice in implant dentistry due to its favorable mechanical properties. Thus, when titanium abutments are indicated, gold anodization of titanium is advocated. Zirconia abutments also displayed significantly smaller spectrophotometric gingival color difference $(\Delta \mathrm{E})$ compared with titanium in a similar study. 
medRxiv preprint doi: https://doi.org/10.1101/2020.05.09.20096271; this version posted May 13, 2020. The copyright holder for this preprint (which was not certified by peer review) is the author/funder, who has granted medRxiv a license to display the preprint in perpetuity.

All rights reserved. No reuse allowed without permission.

Although $\Delta \mathrm{E}$ difference of 3 units is considered by some authors as an indicator for visible mismatch in color, according to other authors on color stability, a color change is said to be clinically visible if $\Delta \mathrm{E}$ values are higher than 3.7 units. ${ }^{36,73,76}$

In this meta-analysis, a total of eight studies conducted in the recent past were considered and two separate analyses were conducted for two different outcomes in order to compare zirconia implants with titanium implants.

Five studies ${ }^{5,17,19,27,37}$ were analyzed for marginal bone loss (MBL) out of which four studies demonstrated similar MBL around both zirconia and titanium implants. A study conducted by Osman et al. ${ }^{19}$ revealed significantly less amount of bone loss around titanium implants when compared with that of zirconia implants. No heterogeneity was detected among the studies used for assessing marginal bone loss around the implants and pooled estimates revealed that the marginal bone loss reduction between both the groups and results of analysis among these studies proved to be significant.

Out of the four studies ${ }^{5,28,29,36}$ included for analyzing aesthetic outcomes, three studies have reported that both titanium and zirconia abutments caused similar discoloration of soft tissue compared with gingiva of natural tooth. In a study conducted by Martinez-Rus et al. ${ }^{36}$ slightly lower $\Delta \mathrm{E}$ values were demonstrated by Zirconia implants. A considerable heterogeneity was detected among these studies and pooled estimates showed that zirconia implants have shown similar results as that of titanium implants and there were no significant differences between the two groups of implants. This heterogeneity may be mainly due to differences in the follow-up time periods, imbalanced amount of restorations among two groups, limited number of patients and other variations among studies.

There are several limitations in this meta-analysis. Only two outcomes have been 
medRxiv preprint doi: https://doi.org/10.1101/2020.05.09.20096271; this version posted May 13, 2020. The copyright holder for this preprint (which was not certified by peer review) is the author/funder, who has granted medRxiv a license to display the preprint in perpetuity.

All rights reserved. No reuse allowed without permission.

evaluated to compare zirconia with titanium implants which would probably be insufficient to prove superiority of zirconia implants compared to titanium implants. Hence, analysis of other properties and characteristics of zirconia implants are required. Only mesial and distal surfaces could be examined as a consequence of MBL being evaluated radiographically. One of the major drawbacks is the lack of long-term studies on zirconia implants. Even the follow-up time periods were not so similar in the above included studies which could have resulted in insignificant or inconsistency in results. The heterogeneity of some studies does not allow us to conduct more individualized analyses. These studies were conducted on a limited number of populations. Both anterior and posterior reconstructions in both maxilla and mandible were considered which may lead to further heterogeneity among studies.

Although there is a requirement of clinical trials to validate these findings, Zirconia implants exhibited certain advantages over conventional Titanium implants. Investigations in the future should focus on well-designed randomized controlled trials with long-term followup. In addition, to further examine the potential of this material, studies pertaining to regenerative procedures around Zirconia implants are essential.

Within limitations, the meta-analysis of randomized controlled trials whose investigators compared the marginal bone loss and aesthetic outcomes in and around zirconia implants and titanium implants revealed that there was no heterogeneity among studies analyzed for marginal bone loss in both the groups and results were significant. Heterogeneity was observed among studies assessing aesthetics using spectrophotometry and CIE-Lab measurements and results revealed not many significant differences between the two groups. For obtaining more definitive and favorable outcomes, further studies with other parameters and long-term follow up are required. 
medRxiv preprint doi: https://doi.org/10.1101/2020.05.09.20096271; this version posted May 13,2020 . The copyright holder for this preprint (which was not certified by peer review) is the author/funder, who has granted medRxiv a license to display the preprint in perpetuity.

\section{REFERENCES}

1) Deliberador TM, Verbicaro T, Minerva L, Scariot R, Giovanini AF, Zielak JC. Horizontal alveolar ridge expansion followed by immediate placement of implants and rehabilitation with zirconia prosthesis. J Ind Soc Periodontol 2017; 21:417-421.

2) Baldini N, D'Elia C, Clementini M, de Albornoz Carrillo A, Sanz M, De MS. Esthetic Outcomes of Single-Tooth Implant-Supported Restorations Using Metal-Ceramic Restorations with Zirconia or Titanium Abutments: A Randomized Controlled Clinical Study. Int J Periodontics Restorative Dent 2016; 36: e59-66.

3) Chiapasco M, Casentini P, Zaniboni M, Corsi E, Anello T. Titanium-zirconium alloy

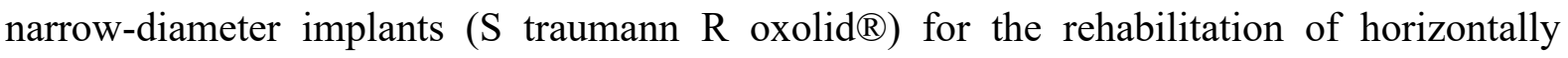
deficient edentulous ridges: prospective study on 18 consecutive patients. Clin Oral Implants Res 2012; 23:1136-1141.

4) Andersson B, Ödman P, Lindvall AM, Lithner B. Single-tooth restorations supported by osseointegrated implants: results and experiences from a prospective study after 2 to 3 years. Int J Oral Maxillofac Implants 1995; 10:702-11.

5) Zembic A, Sailer I, Jung RE, Hämmerle $\mathrm{CH}$. Randomized-controlled clinical trial of customized zirconia and titanium implant abutments for single-tooth implants in canine and posterior regions: 3-year results. Clin Oral Implants Res 2009; 20:802-8.

6) Roehling S, Schlegel KA, Woelfler H, Gahlert M. Performance and outcome of zirconia dental implants in clinical studies: A meta-analysis. Clin Oral Implants Res 2018; 29:135-153.

7) Houshmand A, Donkiewicz P, Smeets R, Jung O, Barbeck M. Incidental finding of a degrading zirconia dental implant 29 months after implantation: Histological and histomorphometrical analysis. J Biomed Mater Res B Appl Biomater 2018; 106:2919- 2923. 
medRxiv preprint doi: https://doi.org/10.1101/2020.05.09.20096271; this version posted May 13,2020 . The copyright holder for this preprint (which was not certified by peer review) is the author/funder, who has granted medRxiv a license to display the preprint in perpetuity.

All rights reserved. No reuse allowed without permission.

8) Nishihara H, Adanez MH, Att W. Current status of zirconia implants in dentistry: preclinical tests. J Prosthodont Res 2019; 63:1-4.

9) Jung RE, Sailer I, Hammerle CH, Attin T, Schmidlin P. In vitro color changes of soft tissues caused by restorative materials. Int J Periodontics Restorative Dent 2007; 27:251-7.

10) Park SE, Da Silva JD, Weber HP, Ishikawa-Nagai S. Optical phenomenon of peri-implant soft tissue. Part I. Spectrophotometric assessment of natural tooth gingiva and peri-implant mucosa. Clin Oral Implants Res 2007; 18:569-74.

11) Mombelli A, Hashim D, Cionca N. What is the impact of titanium particles and biocorrosion on implant survival and complications? A critical review. Clin Oral Implants Res $2018 ; 29: 37-53$.

12) Fretwurst T, Nelson K, Tarnow DP, Wang HL, Giannobile WV. Is metal particle release associated with peri-implant bone destruction? An emerging concept. J Dent Res 2018; 97:25965.

13) Thomas P, Iglhaut G, Wollenberg A, Cadosch D, Summer B. Allergy or tolerance: reduced inflammatory cytokine response and concomitant IL-10 production of lymphocytes and monocytes in symptom-free titanium dental implant patients. Biomed Res Int 2013; 2013:539834.

14) Fage SW, Muris J, Jakobsen SS, Thyssen JP. Titanium: a review on exposure, release, penetration, allergy, epidemiology, and clinical reactivity. Contact Dermatitis 2016; 74:32345.

15) Sicilia A, Cuesta S, Coma G, Arregui I, Guisasola C, Ruiz E, Maestro A. Titanium allergy in dental implant patients: a clinical study on 1500 consecutive patients. Clin Oral Implants Res 2008; 19:823-35. 
medRxiv preprint doi: https://doi.org/10.1101/2020.05.09.20096271; this version posted May 13,2020 . The copyright holder for this preprint (which was not certified by peer review) is the author/funder, who has granted medRxiv a license to display the preprint in perpetuity. All rights reserved. No reuse allowed without permission.

16) Pigatto PD, Guzzi G, Brambilla L, Sforza C. Titanium allergy associated with dental implant failure. Clin Oral Implants Res 2009; 20:857.

17) Payer M, Heschl A, Koller M, Arnetzl G, Lorenzoni M, Jakse N. All-ceramic restoration of zirconia two-piece implants-a randomized controlled clinical trial. Clin Oral Implants Res $2015 ; 26: 371-6$.

18) Kohal RJ, Knauf M, Larsson B, Sahlin H, Butz F. One-piece zirconia oral implants: oneyear results from a prospective cohort study. 1. Single tooth replacement. J Clin Periodontol 2012; 39:590-7.

19) Osman RB, Swain MV, Atieh M, Ma S, Duncan W. Ceramic implants (Y-TZP): are they a viable alternative to titanium implants for the support of overdentures? A randomized clinical trial. Clin Oral Implants Res 2014; 25:1366-77.

20) Lorenz J, Giulini N, Hölscher W, Schwiertz A, Schwarz F, Sader R. Prospective controlled clinical study investigating long-term clinical parameters, patient satisfaction,

and microbial contamination of zirconia implants. Clin Implant Dent Relat Res 2019; 21:26371.

21) Piconi C, Maccauro G. Zirconia as a ceramic biomaterial. Biomaterials 1999; 20:1- 25.

22) Spies BC, Sperlich M, Fleiner J, Stampf S, Kohal RJ. Alumina reinforced zirconia implants: 1-year results from a prospective cohort investigation. Clin Oral Implants Res 2016; 27:481-90.

23) Jung RE, Holderegger C, Sailer I, Khraisat A, Suter A, Hämmerle CH. The effect of allceramic and porcelain-fused-to-metal restorations on marginal peri-implant soft tissue color: a randomized controlled clinical trial. Int J Periodontics Restorative Dent 2008; 28:357-65. 
medRxiv preprint doi: https://doi.org/10.1101/2020.05.09.20096271; this version posted May 13,2020 . The copyright holder for this preprint (which was not certified by peer review) is the author/funder, who has granted medRxiv a license to display the preprint in perpetuity. All rights reserved. No reuse allowed without permission.

24) Belser UC, Schmid B, Higginbottom F, Buser D. Outcome analysis of implant restorations located in the anterior maxilla: a review of the recent literature. Int J Oral Maxillofac Implants 2004; 19 Suppl:30-42.

25) Cionca N, Hashim D, Cancela J, Giannopoulou C, Mombelli A. Pro-inflammatory cytokines at zirconia implants and teeth. A cross-sectional assessment. Clin Oral Investig 2016; 20:2285-2291.

26) Siddiqi A, Duncan WJ, De Silva RK, Zafar S. One-piece zirconia ceramic versus titanium implants in the jaw and femur of a sheep model: a pilot study. Biomed Res Int 2016; 2016:6792972.

27) Koller M, Steyer E, Theisen K, Stagnell S, Jakse N, Payer M. Two-piece zirconia versus titanium implants after 80 months: Clinical outcomes from a prospective randomized pilot trial. Clin Oral Implants Res 2020; 31:388-396.

28) Sailer I, Zembic A, Jung RE, Siegenthaler D, Holderegger C, Hämmerle CH. Randomized controlled clinical trial of customized zirconia and titanium implant abutments for canine and posterior single-tooth implant reconstructions: preliminary results at 1 year of function. Clin Oral Implants Res 2009; 20:219-25.

29) Bösch A, Jung RE, Sailer I, Goran B, Hämmerle CH, Thoma DS. Single-tooth replacement using dental implants supporting all-ceramic and metal-based reconstructions: Results at 18 months of loading. Int J Periodontics Restorative Dent 2018; 38:173-9.

30) Brandenberg FD, Sailer I, Fehmer V, Büchi DL, Hämmerle CH, Thoma DS. Randomized controlled clinical pilot study of all-ceramic single-tooth implant reconstructions: clinical and microbiological outcomes at one year of loading. Clin Oral Implants Res 2017; 28:406-413.

31) Jemt, T. Regeneration of gingival papillae after single-implant treatment. Int J Periodontics 
medRxiv preprint doi: https://doi.org/10.1101/2020.05.09.20096271; this version posted May 13,2020 . The copyright holder for this preprint (which was not certified by peer review) is the author/funder, who has granted medRxiv a license to display the preprint in perpetuity.

Restorative Dent 1997; 17:326-333.

32) Meijer HJ, Stellingsma K, Meijndert L, Raghoebar GM. A new index for rating aesthetics of implant-supported single crowns and adjacent soft tissues-the Implant Crown Aesthetic Index: A pilot study on validation of a new index. Clin Oral Implants Res 2005; 16:645-649.

33) Fürhauser R, Florescu D, Benesch T, Haas R, Mailath G, Watzek G. Evaluation of soft tissue around single-tooth implant crowns: the pink esthetic score. Clin Oral Implants Res $2005 ; 16: 639-644$.

34) Belser UC, Grütter L, Vailati F, Bornstein MM, Weber HP, Buser D. Outcome evaluation of early placed maxillary anterior single-tooth implants using objective esthetic criteria: a cross-sectional, retrospective study in 45 patients with a 2-to 4-year follow-up using pink and white esthetic scores. J Periodontol 2009; 80:140-51.

35) Barwacz CA, Stanford CM, Diehl UA, Qian F, Cooper LF, Feine J, McGuire M. Electronic assessment of peri-implant mucosal esthetics around three implant- abutment configurations: a randomized clinical trial. Clin Oral Implants Res 2016; 27:707-15.

36) Martínez-Rus F, Prieto M, Salido MP, Madrigal C, Özcan M, Pradíes G. A Clinical Study Assessing the Influence of Anodized Titanium and Zirconium Dioxide Abutments and Periimplant Soft Tissue Thickness on the Optical Outcome of Implant-Supported Lithium Disilicate Single Crowns. Int J Oral Maxillofac Implants 2017; 32:156-163.

37) Zembic A, Bösch A, Jung RE, Hämmerle CH, Sailer I. Five-year results of a randomized controlled clinical trial comparing zirconia and titanium abutments supporting single-implant crowns in canine and posterior regions. Clin Oral Implants Res 2013; 24:384-90.

38) Borgonovo A, Censi R, Dolci M, Vavassori V, Bianchi A, Maiorana C. Use of endosseous one-piece yttrium-stabilized zirconia dental implants in premolar region: a two-year clinical 
medRxiv preprint doi: https://doi.org/10.1101/2020.05.09.20096271; this version posted May 13, 2020. The copyright holder for this preprint (which was not certified by peer review) is the author/funder, who has granted medRxiv a license to display the preprint in perpetuity. All rights reserved. No reuse allowed without permission.

preliminary report. Minerva Stomatol 2011; 60:229-41.

39) Gahlert M, Kniha H, Weingart D, Schild S, Gellrich NC, Bormann KH. A prospective clinical study to evaluate the performance of zirconium dioxide dental implants in single-tooth gaps. Clin Oral Implants Research 2016; 27:e176-84.

40) Spies BC, Balmer M, Patzelt SB, Vach K, Kohal RJ. Clinical and patient-reported outcomes of a zirconia oral implant: Threeyear results of a prospective cohort investigation. $\mathbf{J}$ Dent Res 2015; 94:1385-1391.

41) Elnayef B, Lazaro A, Suárez-López del Amo F, Galindo-Moreno P, Wang HL, GargalloAlbiol J, Hernandez-Alfaro F. Zirconia Implants as an Alternative to Titanium: A Systematic Review and Meta-Analysis. Int J Oral Maxillofac Implants 2017; 32:e125- e134.

42) Weingart D, Steinemann S, Schilli W, et al. Titanium deposition in regional lymph nodes after insertion of titanium screw implants in maxillofacial region. Int J Oral Maxillofac Surg $1994 ; 23: 450-452$.

43) Manzano G, Herrero LR, Montero J. Comparison of clinical performance of zirconia implants and titanium implants in animal models: A systematic review. Int J Oral Maxillofac Implants 2014; 29:311-320.

44) Wenz HJ, Bartsch J, Wolfart S, Kern M. Osseointegration and clinical success of zirconia dental implants: A systematic review. Int J Prosthodont 2008; 21:27-36.

45) Siddiqi A, Payne AG, De Silva RK, Duncan WJ. Titanium allergy: Could it affect dental implant integration? Clin Oral Implants Res 2011; 22:673-680.

46) Javed F, Al-Hezaimi K, Almas K, Romanos GE. Is titanium sensitivity associated with allergic reactions in patients with dental implants? A systematic review. Clin Implant Dent Relat Res 2013; 15:47-52. 
medRxiv preprint doi: https://doi.org/10.1101/2020.05.09.20096271; this version posted May 13,2020 . The copyright holder for this preprint (which was not certified by peer review) is the author/funder, who has granted medRxiv a license to display the preprint in perpetuity.

All rights reserved. No reuse allowed without permission.

47) Kan JY, Rungcharassaeng K, Lozada JL, Zimmerman G. Facial gingival tissue stability following immediate placement and provisionalization of maxillary anterior single implants: A 2- to 8-year follow-up. Int J Oral Maxillofac Implants 2011; 26:179- 187.

48) Piconi C, Maccauro G, Muratori F, Brach Del Prever E. Alumina and zirconia ceramics in joint replacements. J Appl Biomater Biomech 2003; 1:19-32.

49) Andreiotelli M, Wenz HJ, Kohal RJ. Are ceramic implants a viable alternative to titanium implants? A systematic literature review. Clin Oral Implants Res 2009; 20:s32-s47.

50) Kohal RJ, Weng D, Bächle M, Strub JR. Loaded custom-made zirconia and titanium implants show similar osseointegration: An animal experiment. J Periodontol 2004; 75:12621268.

51) Oliva J, Oliva X, Oliva JD. Five-year success rate of 831 consecutively placed zirconia dental implants in humans: A comparison of three different rough surfaces. Int $\mathrm{J}$ Oral Maxillofac Implants 2010; 25:336-344.

52) Akagawa Y, Ichikawa Y, Nikai H, Tsuru H. Interface histology of unloaded and early loaded partially stabilized zirconia endosseous implant in initial bone healing. J Prosthet Dent $1993 ; 69: 599-604$.

53) Scarano A, Di Carlo F, Quaranta M, Piattelli A. Bone response to zirconia ceramic implants: an experimental study in rabbits. J Oral Implantol 2003; 29:8-12.

54) Borgonovo AE, Fabbri A, Vavassori V, Censi R, Maiorana C. Multiple teeth replacement with endosseous one-piece yttrium-stabilized zirconia dental implants. Med Oral Patol Oral Cir Bucal 2012; 17:e981-e987.

55) Quirynen M, van Steenberghe D. Bacterial colonization of the internal part of two- stage implants. An in vivo study. Clin Oral Implants Res 1993; 4:158-61. 
medRxiv preprint doi: https://doi.org/10.1101/2020.05.09.20096271; this version posted May 13,2020 . The copyright holder for this preprint (which was not certified by peer review) is the author/funder, who has granted medRxiv a license to display the preprint in perpetuity.

All rights reserved. No reuse allowed without permission.

56) Tarnow DP, Cho SC, Wallace SS. The effect of inter-implant distance on the height of inter-implant bone crest. J Periodontol 2000; 71:546-5.

57) Lindquist LW, Carlsson GE, Jemt T. A prospective 15-year follow-up study of mandibular fixed prostheses supported by osseointegrated implants. Clinical results and marginal bone loss. Clin Oral Implants Res 1996; 7:329-36.

58) Scarano A, Piattelli M, Caputi S, Favero GA, Piattelli A. Bacterial adhesion on commercially pure titanium and zirconium oxide disks: an in vivo human study. J Periodontol $2004 ; 75: 292-6$.

59) Nascimento CD, Pita MS, Fernandes FH, Pedrazzi V, de Albuquerque Junior RF, Ribeiro RF. Bacterial adhesion on the titanium and zirconia abutment surfaces. Clin Oral Implants Res $2014 ; 25: 337-343$

60) Vechiato-Filho AJ, Pesqueira AA, De Souza GM, dos Santos DM, Pellizzer EP, Goiato MC. Are zirconia implant abutments safe and predictable in posterior regions? a systematic review and meta-analysis. Int J Prosthodont 2016; 29: 233-244.

61) Staubli N, Walter C, Schmidt JC, Weiger R, Zitzmann NU. Excess cement and the risk of peri-implant disease-a systematic review. Clin Oral Implants Res 2017; 28:1278-1290.

62) Korsch M, Robra BP, Walther W. Cement-associated signs of inflammation: retrospective analysis of the effect of excess cement on peri-implant tissue. Int J Prosthodont 2015; 28:11-8.

63) Wang QQ, Dai R, Cao CY, Fang H, Han M, Li QL. One-time versus repeated abutment connection for platform-switched implant: A systematic review and meta-analysis. PloS One 2017; 12: e0186385.

64) Esposito M, Bressan E, Grusovin MG, D'Avenia F, Neumann K, Sbricoli L, Luongo G. Do repeated changes of abutments have any influence on the stability of peri-implant tissues? One- 
medRxiv preprint doi: https://doi.org/10.1101/2020.05.09.20096271; this version posted May 13,2020 . The copyright holder for this preprint (which was not certified by peer review) is the author/funder, who has granted medRxiv a license to display the preprint in perpetuity.

All rights reserved. No reuse allowed without permission.

year post-loading results from a multicentre randomised controlled trial. Eur J Oral Implantol $2017 ; 10: 57-72$.

65) Glauser R, Sailer I, Wohlwend A, Studer S, Schibli M, Schärer P. Experimental zirconia abutments for implant-supported single-tooth restorations in esthetically demanding regions: 4-year results of a prospective clinical study. Int J Prosthodont 2004; 17:285-290.

66) Welander M, Abrahamsson I, Berglundh T. The mucosal barrier at implant abutments of different materials. Clin Oral Implants Res 2008; 19:635-41.

67) Ho DK, Ghinea R, Herrera LJ, et al. Color range and color distribution of healthy human Gingiva: a prospective clinical study. Sci Rep 2015; 5:18498.

68) Gil MS, Ishikawa-Nagai S, Elani HW, Da Silva JD, Kim DM, Tarnow D, Schulze-Späte U, Bittner N. A prospective clinical trial to assess the optical efficacy of pink neck implants and pink abutments on soft tissue esthetics. J Esthet Restor Dent 2017; 29:409-15.

69) Thoma DS, Brandenberg F, Fehmer V, Knechtle N, Hämmerle CH, Sailer I. The esthetic effect of veneered zirconia abutments for single-tooth implant reconstructions: A randomized controlled clinical trial. Clin Implant Dent Relat Res 2016; 18:1210-7.

70) Berglundh T, Lindhe J, Ericsson I, Marinello CP, Liljenberg B, Thornsen P. The soft tissue barrier at implants and teeth. Clin Oral Implants Res 1991; 2:81-90.

71) Berglundh T, Lindhe J, Jonsson K, Ericsson I. The topography of the vascular systems in the periodontal and peri-implant tissues in the dog. J Clin Periodontol 1994; 21:189-193.

72) Kleinheinz J, Büchter A, Fillies T, Joos U. Vascular basis of mucosal color. Head Face Med 2005; 1:4.

73) Johnston, W.M. \& Kao, E.C. Assessment of appearance match by visual observation and 
medRxiv preprint doi: https://doi.org/10.1101/2020.05.09.20096271; this version posted May 13, 2020. The copyright holder for this preprint (which was not certified by peer review) is the author/funder, who has granted medRxiv a license to display the preprint in perpetuity.

All rights reserved. No reuse allowed without permission.

clinical colorimetry. J Dent Res 1989; 68:819-822.

74) Jung RE, Pjetursson BE, Glauser R, Zembic A, Zwahlen M, Lang NP. A systematic review of the survival and complication rates of implant supported single crowns (SCs) after an observation period of at least 5 years. Clin Oral Implants Res 2008b; 19:119-130.

75) Kim A, Campbell SD, Viana MA, Knoernschild KL. Abutment material effect on periimplant soft tissue color and perceived esthetics. J Prosthodont 2016; 25:634-40.

76) Okubo SR, Kanawati A, Richards MW, Childressd S. Evaluation of visual and instrument shade matching. J Prosthet Dent 1998; 80:642-8. 
medRxiv preprint doi: https://doi.org/10.1101/2020.05.09.20096271; this version posted May 13, 2020. The copyright holder for this preprint (which was not certified by peer review) is the author/funder, who has granted medRxiv a license to display the preprint in perpetuity.

All rights reserved. No reuse allowed without permission.

Table 1: Characteristics of the studies included.

\begin{tabular}{|c|c|c|c|c|c|c|}
\hline Author & Year & $\begin{array}{l}\text { Study } \\
\text { design }\end{array}$ & $\begin{array}{r}\text { Sample } \\
\text { (total) }\end{array}$ & $\begin{array}{l}\text { Mean } \\
\text { age (in } \\
\text { years) }\end{array}$ & Gender & $\begin{array}{l}\text { Treatment groups with } \\
\text { sample size at time of } \\
\text { evaluation. }\end{array}$ \\
\hline Koller et al. ${ }^{27}$ & 2020 & $\begin{array}{l}\text { Randomized } \\
\text { controlled trial }\end{array}$ & $\begin{array}{c}\mathrm{n}=31 \\
\text { implants }\end{array}$ & $\begin{array}{l}46 \\
(24-77)\end{array}$ & $\begin{array}{l}13 \text { males } \\
9 \text { females }\end{array}$ & $\begin{array}{l}\text { Test: Zirconia implants }(n=14) \\
\text { Control: Titanium implants }(n=14)\end{array}$ \\
\hline Osman et al. ${ }^{19}$ & 2014 & $\begin{array}{l}\text { Randomized } \\
\text { controlled trial }\end{array}$ & $\begin{array}{l}\mathrm{n}=129 \\
\text { implants }\end{array}$ & $\begin{array}{l}62 \\
(46-80)\end{array}$ & $\begin{array}{l}15 \text { males } \\
4 \text { females }\end{array}$ & $\begin{array}{l}\text { Test: Zirconia implants }(\mathrm{n}=56) \\
\text { Control: Titanium implants }(\mathrm{n}=73)\end{array}$ \\
\hline Zembic et al. ${ }^{37}$ & 2013 & $\begin{array}{l}\text { Randomized } \\
\text { controlled trial }\end{array}$ & $\begin{array}{c}\mathrm{n}=40 \\
\text { implants }\end{array}$ & $\begin{array}{l}41.3 \\
( \pm 18)\end{array}$ & $\begin{array}{l}8 \text { males } \\
14 \text { females }\end{array}$ & $\begin{array}{l}\text { Test: Zirconia abutment supporting all } \\
\text { ceramic crown in single implants }(n=18) \\
\text { Control: Titanium abutment supporting } \\
\text { metal ceramic crown in single implants } \\
(n=10) . \text { Follow up period of } 60 \text { months }\end{array}$ \\
\hline Zembic et al. ${ }^{5}$ & 2009 & $\begin{array}{l}\text { Randomized } \\
\text { controlled trial }\end{array}$ & $\begin{array}{c}\mathrm{n}=40 \\
\text { implants }\end{array}$ & $\begin{array}{l}41.3 \\
( \pm 18)\end{array}$ & $\begin{array}{l}8 \text { males } \\
14 \text { females }\end{array}$ & $\begin{array}{l}\text { Test: Zirconia abutment supporting all } \\
\text { ceramic crown in single implants }(n=18) \\
\text { Control: Titanium abutment supporting } \\
\text { metal ceramic crown in single implants } \\
(n=10) \text {. Follow up period of } 36 \text { months }\end{array}$ \\
\hline Payer et al. ${ }^{17}$ & 2014 & $\begin{array}{l}\text { Randomized } \\
\text { controlled trial }\end{array}$ & $\begin{array}{c}\mathrm{n}=31 \\
\text { implants }\end{array}$ & $\begin{array}{l}46 \\
(24-77)\end{array}$ & $\begin{array}{l}13 \text { males } \\
9 \text { females }\end{array}$ & $\begin{array}{l}\text { Test: Zirconia implants }(n=16) \\
\text { Control: Titanium implants }(n=15)\end{array}$ \\
\hline Sailer et al. ${ }^{28}$ & 2009 & $\begin{array}{l}\text { Randomized } \\
\text { controlled trial }\end{array}$ & $\begin{array}{c}\mathrm{n}=40 \\
\text { implants }\end{array}$ & $\begin{array}{l}41.3 \\
( \pm 18)\end{array}$ & $\begin{array}{c}8 \text { males } \\
14 \text { females }\end{array}$ & $\begin{array}{l}\text { Test: Zirconia abutment placed on } \\
\text { single implants }(n=19) \\
\text { Control: Titanium abutment placed on } \\
\text { single implants }(n=12) \text {. Follow up period } \\
\text { of } 12 \text { months }\end{array}$ \\
\hline Bosch et al. ${ }^{29}$ & 2018 & $\begin{array}{l}\text { Randomized } \\
\text { controlled trial }\end{array}$ & $\begin{array}{c}\mathrm{n}=28 \\
\text { implants }\end{array}$ & $\begin{array}{l}43.7 \pm \\
13.8\end{array}$ & $\begin{array}{l}13 \text { males } \\
16 \text { females }\end{array}$ & $\begin{array}{l}\text { Test: Customized Zirconia abutment } \\
\text { placed on single implants }(n=12) \\
\text { Control: Customized Titanium abutment } \\
\text { placed on single implants }(n=16)\end{array}$ \\
\hline $\begin{array}{l}\text { Martinez-Rus et } \\
\text { al. } 36\end{array}$ & 2017 & $\begin{array}{l}\text { Randomized } \\
\text { controlled } \\
\text { trial }\end{array}$ & $\begin{array}{c}\mathrm{n}=20 \\
\text { implants }\end{array}$ & 53.4 & $\begin{array}{c}9 \text { males } \\
11 \text { females }\end{array}$ & $\begin{array}{l}\text { Test: Customized Zirconia abutment } \\
\text { placed on single implants }(\mathrm{n}=10) \\
\text { Control: Customized Titanium abutment } \\
\text { placed on single implants }(\mathrm{n}=10)\end{array}$ \\
\hline
\end{tabular}


medRxiv preprint doi: https://doi.org/10.1101/2020.05.09.20096271; this version posted May 13,2020 . The copyright holder for this preprint (which was not certified by peer review) is the author/funder, who has granted medRxiv a license to display the preprint in perpetuity.

All rights reserved. No reuse allowed without permission.

Figure 1: Flow diagram presenting the review process of studies considered for metaanalysis.

Citations screened for titles and abstracts $(n=58)$

Article review and application of inclusion criteria $(n=8)$

Eligible randomized controlled trials identified $(n=8)$ 
medRxiv preprint doi: https://doi.org/10.1101/2020.05.09.20096271; this version posted May 13, 2020. The copyright holder for this preprint (which was not certified by peer review) is the author/funder, who has granted medRxiv a license to display the preprint in perpetuity.

All rights reserved. No reuse allowed without permission.

Figure 2. Forest plot of meta-analysis for evaluation of marginal bone loss.

Studies

Koller et al.

Osman et al.

Zembic et al.

Zembic, Sailer et al.

Payer et al

Overall $\left(a^{\wedge} 2=0 \%, P=0.536\right)$
Estimate (95* C.I.)

$0.210(-0.361,0.701)$

$0.240(0.054,0.426)$

$0.000(-0.569,0.568)$

$-0.400(-1.173,0.373)$

$0.050(-0.566,0.666)$

$0.179(0.020,0.338)$

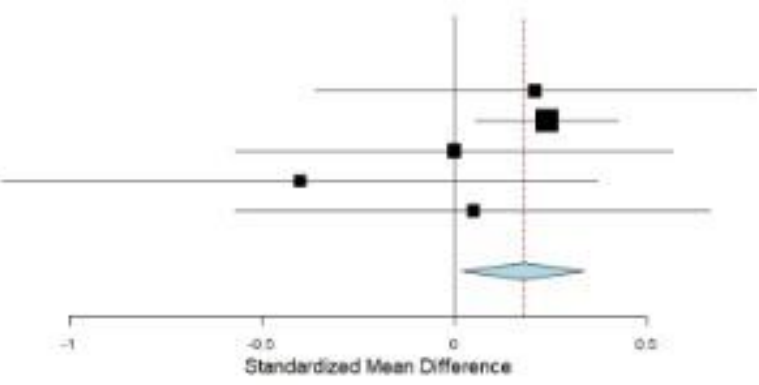

Standardized Mean Difference 
medRxiv preprint doi: https://doi.org/10.1101/2020.05.09.20096271; this version posted May 13, 2020. The copyright holder for this preprint (which was not certified by peer review) is the author/funder, who has granted medRxiv a license to display the preprint in perpetuity.

All rights reserved. No reuse allowed without permission.

Figure 3. Forest plot of meta-analysis for evaluation of aesthetics using spectrophotometry.

Studies

Zembic et al.

Sailer et al

Bosch et al.

Martinez-rus et al.

Overall $(1 \wedge 2=82.67 \%, P<0.001)$

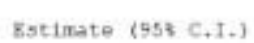

$2.500(-0.437,5.437)$

$0.300\langle-2,699, \quad 3,299\rangle$

$2.000(-1,919,5.919)$

$-5.500(-8.394,-2.606)$

$-0.242(-4.026,3.542)$

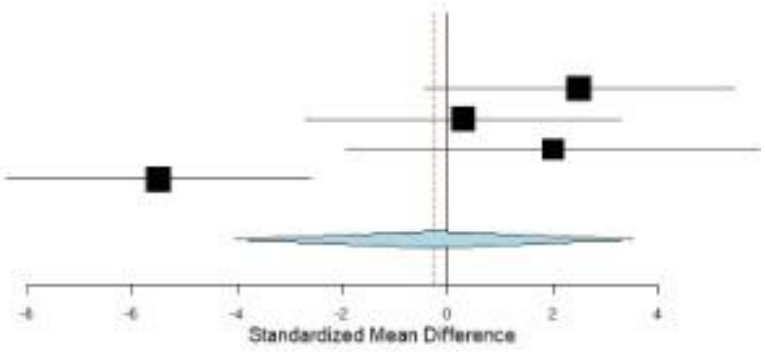

